ISSN e-2594-1100

en-claves del pensamiento / núm. 30 / julio-diciembre / 2021 / e445

https://doi.org/10.46530/ecdp.v0i30.445 ARTÍCULOS

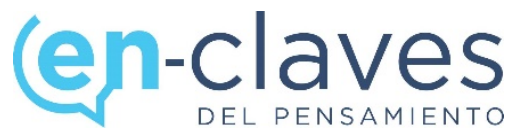

\title{
LITERATURA Y TEATRO EN EL CINISMO DE DIÓGENES DE SÍNOPE Y NIETZSCHE
}

Literature and Theatre in the Cynicism of Diogenes the Cynic and Nietzsche

Andrés Camilo Torres Estrada, Universidad de los Andes, Colombia Correo electrónico: ac.torres410@uniandes.edu.co

Recibido: $11 / 27 / 2020$

Aceptado: 09/08/2021

Publicado: 10/01/2021

Resumen. Este artículo relaciona la biografía de Diógenes de Sínope, hecha por Diógenes Laercio, y Ecce Homo, la autobiografía de Friedrich Nietzsche. A través de la concepción del teatro, el propósito es relacionar ambos textos biográficos encontrando una escritura filosófica particular que se separa de las formas usuales de la teoría. A partir de este análisis es posible demostrar que ambos autores consideraban inseparables la forma y el contenido de su filosofía, que tenían una idea de la práctica indiferenciable de la teoría, y que sus maneras particulares de expresarse constituían por sí mismas una forma de pensamiento: la resistencia al sentido último, lo que los une al teatro y a la literatura.

Palabras clave: Diógenes, Nietzsche, cinismo, teatro, literatura.

Abstract. This article connects the biography of Diogenes of Sinope written by Diogenes Laertius and Friedrich Nietzsche's autobiography, Ecce Homo. Through the notion of theatre, our purpose is to compare the two biographical texts in order to find a particular philosophical writing that is different from the usual forms of theory. From this analysis it is possible to show that both authors considered inseparable the form and content of their philosophies; they regarded practice as indistinguishable from theory and that their particular ways of expressing constituted themselves a way of thinking: resistance to meaning.

Keywords: Diogenes, Nietzsche, cynicism, theatre, literature.

Cómo citar: Torres Estrada, A. C. (2021). Literatura y teatro en el cinismo de Diógenes de Sínope y Nietzsche. En-claves del pensamiento, O(30), e445. doi: https://doi.org/10.46530/ecdp.v0i30.445

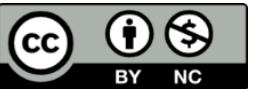

Esta obra está protegida bajo una Licencia

Creative Commons Atribución - No comercial

4.0 Internacional 


\begin{abstract}
"Me he narrado a mí mismo con un cinismo que llegará a ser universalmente histórico. El libro se titula Ecce homo"

Friedrich Nietzsche,

"Carta de a Georg Brandes, 20 de noviembre de 1888"
\end{abstract}

En su Lección inaugural, Roland Barthes demostraba en 1977 cómo la literatura era una forma de abjurar del poder del que no podía, sin embargo, escapar:

Así no hay que sorprenderse si, en el horizonte imposible de la anarquía del lenguaje —allí donde la lengua intenta escapar a su propio poder, a su propio servilismo-, se encuentra algo que guarda relación con el teatro. Para designar lo imposible de la lengua he citado a dos autores: Kierkegaard y Nietzsche. Sin embargo, ambos han escrito, pero los dos lo hicieron en el reverso mismo de la identidad, en el juego, en el riesgo extraviado del nombre propio: uno mediante el recurso incesante a la seudonimia, el otro colocándose, hacia el fin de su vida de escritura, $[\ldots]$ en los límites del histrionismo. Puede decirse que la tercera fuerza de la literatura, su fuerza propiamente semiótica, reside en actuar los signos en vez de destruirlos, en meterlos en una maquinaria de lenguaje cuyos muelles y seguros han saltado; en resumen, en instituir, en el seno mismo de la lengua servil, una verdadera heteronimia de las cosas. ${ }^{1}$

Varios elementos hay en esta cita para empezar a desenvolver las ideas de este texto. En primera instancia, quisiera explicitar que se nombre a Nietzsche y a Kierkegaard, filósofos, como ejemplos para hablar de una de las fuerzas de la literatura. Existe abundante bibliografía que señala el carácter literario de la obra nietzscheana, pero la forma específica en la que Barthes aborda el problema es lo que me interesa: al lado de literatura y filosofía aparece un tercer factor: el teatro. Barthes habla del fin de la vida de escritura de Nietzsche, es decir, Ecce homo, su autobiografía: la puesta en escena de sí mismo en la escritura. Para efectos de este trabajo, a su lado, una segunda obra de teatro (que interrumpe constantemente la primera, que en ocasiones comparte trama y escenario, que mezcla indiferentemente escenas de una y otra): la vida de Diógenes de Sínope, el cínico, retratado en el pasaje biográfico de Diógenes Laercio; la puesta en escena, en la escritura, de otro.

Nietzsche siempre resaltó en la filosofía antigua su carácter práctico como opción de vida, y entre los pocos predecesores que admitió tuvo a algunos de los griegos presocráticos

\footnotetext{
${ }^{1}$ Roland Barthes, Lección inaugural (México: Siglo XXI, 1993), 133.
} 
y helenísticos. ${ }^{2}$ Por otro lado, un texto como el de Laercio puede confirmar que en la antigüedad la filosofía se juzgara por su consecuencia en la vida, por la actitud del filósofo en su vida respecto a su doctrina. En Vidas, opiniones y sentencias de los filósofos más ilustres, Laercio recogió en forma de biografía hechos fundamentales de la vida de los filósofos, de tal manera que el lector pudiera contrastarlos con la doctrina que aparecía en el mismo relato. Así pues, no es de extrañar que Nietzsche haya escrito una autobiografía, aunque se trate en definitiva de una muy particular. Sin embargo, ¿cómo relacionar dos filosofías (pero sobre todo dos vidas de filósofos) que no sólo están separadas por el tiempo sino por maneras radicalmente diferentes de hacerse? ¿Cómo hablar de una biografía y una autobiografía que retratan, una a un filósofo a partir de anécdotas, apenas algún dato sobre su vida y alguna referencia a su doctrina, y otra a un filósofo capturándose a sí mismo sin mencionar una sola anécdota y donde los comentaristas han visto primordialmente un capítulo más de su filosofía?

Podría responderse que la aproximación es apropiada desde la filosofía como práctica de vida. Desde esta concepción el género biográfico tiene sentido. Sin embargo, lo que estos autores ofrecen como práctica de su filosofía es algo más complejo que un simple ejercicio de su doctrina. Es decir, lo que está en juego aquí va más allá de ejercicios biográficos que dan cuenta de una forma de vivir que se corresponde con la filosofía teórica de sus protagonistas. Hay varios puntos en ambos textos que permiten el acercamiento a Diógenes y a Nietzsche desde un punto de vista dramático, y que cuestionan la división filosofía/vida, teoría/práctica. Me gustaría empezar entonces por los puntos en común de estas dos puestas en escena.

\section{Posibilidades teatrales}

Ante los dos personajes retratados podemos identificar las primeras impresiones que los señalan como particulares. Se trata de personajes histriónicos, exagerados, hiperbólicos, vanidosos, provocadores, intempestivos. Sin embargo, obtenemos esta impresión por medios

\footnotetext{
${ }^{2}$ Cfr. Friedrich Nietzsche, Los filósofos preplatónicos, en Obras Completas II: Escritos filológicos, edición dirigida por D. Sánchez Meca (Madrid: Tecnos, 2013), donde Nietzsche constantemente resalta el carácter consecuente de los filósofos griegos entre vida y doctrina.
} 
diferentes: mientras que en el caso de Diógenes lo reconocemos por los actos que cuentan sus anécdotas y sus dichos, en el caso de Nietzsche lo vemos a partir de sus exclamaciones, sus señalamientos, sus énfasis. Esta diferencia podemos volverla una coincidencia si lo pensamos desde el punto de vista dramático: por un lado, la teatralidad de la anécdota y, por el otro, la teatralidad de la escritura. Es decir, podemos reconocer ciertos elementos propios del teatro - y más específicamente de la comedia, al estilo de Aristófanes - que acontecen en ambos ejercicios biográficos: el juego de palabras — con frecuencia perdido en las traducciones-, los diálogos, los intertextos, las contradicciones, las incoherencias y la primacía de un lenguaje oral, entre otros.

Los juegos de palabras, en primer lugar, están conectados en ambos casos siempre con el humor. De igual forma, mientras los diálogos de Diógenes ocurren siempre con otros personajes a los que se enfrenta, en Nietzsche - cuya autobiografía estaría más relacionada, visiblemente, con un monólogo — el diálogo se hace presente de diferentes maneras: a veces con citas de sus propios textos, otras veces con enemigos suyos (Sócrates), también con otros sí mismos que es (Zaratustra), con otros sí mismos que fue (Schopenhauer, Wagner), con lectores fieles, o con quienes jamás lo han leído - Ecce homo está siempre consciente de un receptor, está escrito para alguien y contra alguien: “¡Escuchádme!, pues yo soy tal y tal. ¡Sobre todo, no me confundáis con otros!”, ${ }^{3}$ dice desde la primera página-.

En los intertextos de obras canónicas, Diógenes se enfrenta a los textos homéricos, mientras que Nietzsche a la Biblia (en las citas que utiliza de Zaratustra hay un constante parafraseo y parodia del Evangelio de Mateo y del Antiguo Testamento); ${ }^{4}$ estos intertextos no solo parodian, sino que se atreven a modificar en contenido y significado las citas, descontextualizándolas y resignificándolas por completo. Por el lado de las incoherencias, ${ }^{5}$

\footnotetext{
${ }^{3}$ Nietzsche, Ecce homo, en Obras Completas IV: Escritos de madurez II, edición dirigida por D. Sánchez Meca (Madrid: Tecnos, 2016), 782.

${ }^{4}$ Cfr. Ibid., 783 y 799.

${ }^{5}$ El problema de la incoherencia parece jugar un papel fundamental en toda la filosofía antigua. Pero esa incoherencia, según Hadot, es una percepción moderna, sólo nos extraña a nosotros: "A propósito de la génesis que hay en mi obra de la noción de filosofía como elección de vida o de la noción de ejercicios espirituales, empecé reflexionando sobre este problema: cómo explicar la incoherencia aparente de algunos filósofos. [...] Siempre me chocó que los historiadores dijeran 'Aristóteles es incoherente', 'san Agustín compone mal'. Y esto me condujo a la idea de que las obras filosóficas de la Antigüedad no se componían para exponer un sistema, sino para producir un efecto de formación: el filósofo quería hacer trabajar los espíritus de sus lectores o auditores para ponerlos en una disposición determinada". Pierre Hadot, La filosofía como forma de vida: conversaciones con Jeannie Carlier y Arnold I. Davidson (Barcelona: Alpha Decay, 2009), 99.
} 
éstas se muestran relativas, pues las obras no se tratan de sistemas expuestos, ${ }^{6}$ sino de personajes, que en el caso de Diógenes defiende la vida frugal, pero es constantemente visto en la taberna, y como Nietzsche que, afirmándose en un momento como decadente, en la página siguiente se niega como tal ("Descontado, pues, que soy un décadent, soy también su antítesis"). ${ }^{7}$ Y respecto a la primacía del lenguaje oral, podemos verla en Laercio, que permite memorizar fácilmente las anécdotas, y en el carácter casi recitativo del texto de Nietzsche, lleno de exclamaciones, preguntas a un público inexistente y respuestas a observaciones que nadie ha hecho. ${ }^{8}$

Aparte de esto, quisiera hacer énfasis en dos aspectos fundamentales. En primer lugar, el destino de ambos personajes: Nietzsche lo dice en repetidas ocasiones, él es el transvalorador de todos los valores. ${ }^{9}$ Y el oráculo también se lo ha confirmado a Diógenes: él es el alterador de la ley de la ciudad. ${ }^{10}$ Este destino compartido los enmarca en un mismo camino expuesto en sus respectivas biografías: el cinismo. Es la conjunción de ambos en esta misma dirección lo que explicaría el humor, la ironía, la parodia de los textos canónicos, etcétera, tal como Bracht Branham lo declara: "The Cynic motto — Deface the Current Coin' - makes joking, parody, and satire not merely a useful rhetorical tool, but an indispensable one, constitutive of Cynic ideology as such". ${ }^{11}$

\footnotetext{
${ }^{6}$ A este respecto, Andrea Lozano-Vásquez afirma: "Diógenes, por su parte, elige géneros menos declarativos: el diálogo, la carta, la tragedia. Aunque seguramente en ellos se manifiestan sus compromisos, la presencia de más de una voz matiza cualquier afirmación". Andrea Lozano-Vásquez, "Simbiosis entre vida y doctrina en Vidas de filósofos ilustres", Simposio Discurso y vida en la Antigüedad (Medellín: Universidad de Antioquia, 2014).

${ }^{7}$ Nietzsche, Ecce homo, 782.

${ }^{8}$ Ejemplo de este caso es uno de los fragmentos más extraños de Ecce homo, que está entre el prólogo y el primer capítulo. Parece difícil clasificar ese pequeño párrafo en el que Nietzsche parece hablarse a sí mismo, pero también el teatro tiene una figura de estas características; se trata del aparte, en el que un personaje dice un parlamento que el público oye, pero los demás personajes no: "Wie sollte ich nicht meinem ganzen Leben dankbar sein? Und so erzähle ich mir mein Leben” KSA VI, 263. [“¿Cómo no debería estar agradecido a mi vida entera? Y así me cuento mi vida a mí mismo". Nietzsche, Ecce homo, 784].

${ }^{9}$ Por primera vez en el primer apartado, del primer capítulo, por ejemplo, Nietzsche, Ecce homo, 787.

${ }^{10}$ Lo que "la ley de la ciudad" significa en ese contexto permite establecer todavía una relación más estrecha con el destino nietzscheano: "Tópolitikón nómisma: 'la valoración política', lo aceptado políticamente como valor y norma". Carlos García Gual (ed.), Vidas, opiniones y sentencias de los filósofos (Madrid: Alianza, 2007), 289, n. 25.

${ }^{11}$ R. Bratch Branham, "Defacing the Currency: Diogenes' Rhetoric and the Invention of Cynism", The Cynics: The Cynic Movement in Antiquity and Its Legacy in Hellenistic Culture and Society (Berkley: University of California, 1997), 93. "La consigna cínica — 'invalidar la moneda en curso' - implica chanza, parodia y sátira no simplemente como una herramienta retórica útil, sino indispensable, constitutiva de la ideología cínica como tal". "Invalidar la moneda en curso: La retórica de Diógenes y la invención del cinismo", Los cínicos (Seix Barral: Barcelona, 2000), 126 (en adelante, facilitaré en el pie de página la traducción de los textos que cite del libro The Cynics de esta traducción realizada por la editorial Seix Barral).
} 
El segundo aspecto, íntimamente relacionado con el primero, tiene que ver con la autocreación de ambos personajes. Mijail Bajtín, que consideraba a Diógenes una "figura tan profundamente novelesca", ${ }^{12}$ le permite a Branham pensar al cínico como un personaje dialógico: “A 'dialogical' figure -'a hero of improvisation not of tradition'- one who refuses 'to be incarnated in the flesh of existing sociohistorical categories' and who takes the 'ideological and linguistic initiative to change the nature of his own image"'. ${ }^{13}$ Esto quiere decir, entre otras cosas, que Diógenes se niega a estar sujetado por algún sentido o significado unívoco; es insobornable e invulnerable porque el corpus de lo que desea, de lo que defiende, de 'lo suyo', no es posible delimitarlo. Como insiste Bajtín, "Diogenes made himself 'an object of experimentation and representation",; 14 esto es, se ha puesto en juego, en escena, tal como Nietzsche dice haber empezado su camino para llegar a ser lo que se es, dejándose llevar inclusive por los caminos incorrectos:

Dass Man wird, was man ist, setzt voraus, dass man nicht im Entferntesten ahnt, was man ist. Aus diesem Gesichtspunkte haben selbst die Fehlgriffe des Lebens ihren eignen Sinn und Werth, de zeiweiligen Nebenwege und Abwege, die Verzögerungen, die 'Bescheidenheiten', der Ernst, auf Aufgaben verschwendet, die jenseits der Aufgabe liegen. ${ }^{15}$

Ambos nos dan la idea de un personaje de una obra que se va configurando a partir de las experiencias que va viviendo, sin ensayo. El actor no es consciente del todo del personaje que es, no tiene un plan, y se va haciendo a medida que van pasando las escenas, entregado a la experimentación y la improvisación. ${ }^{16}$

\footnotetext{
${ }^{12}$ Mijael Bajtín, Teoría y estética de la novela: trabajos de investigación (Madrid: Taurus, 1989), 483.

${ }^{13}$ Branham, "Defacing the Currency", 86. ["una 'figura dialógica' — 'un héroe de la improvisación, no de la tradición'-, alguien que rechaza 'encarnarse en las categorías sociohistóricas existentes' y que toma la ‘iniciativa ideológica y lingüística para cambiar la naturaleza de su propia imagen”. Los cínicos, 117].

${ }^{14}$ Ibid., 87.

${ }^{15}$ KSA VI, 293. ["El llegar a ser lo que uno es presupone el no divisar ni de lejos lo que se es. $\{\ldots\}$ incluso las equivocaciones de la vida, los puntuales caminos secundarios y desvíos, las demoras, las 'modestias', la seriedad desperdiciada en tareas situadas más allá de la tarea posee su propio sentido y valor". Nietzsche, Ecce homo, 806; y también: "Siempre estoy a la altura del azar; para ser dueño de mí tengo que estar desprevenido". Ibid., 799].

${ }^{16}$ Lo que nos dice Ecce homo sobre Nietzsche, sobre el sujeto de la autobiografía, sobre esa primera persona que narra, es que ése que es siempre está llegando a ser el que es. Hay que observar que lo que promete el subtítulo (Cómo se llega a ser lo que se es) es en primer lugar el proceso, el cómo. Miguel Ángel de Barrenechea, hace énfasis también en este aspecto: "Aunque la frase diga que es necesario 'Llegar a ser el que tú eres' - lo que parecería aludir a una esencia fija —, el verbo destaca — 'Llega a' - que nuestro 'ser' está siempre en tránsito, en vías de realización". Miguel Ángel de Barrenechea, "Ecce homo: La universalidad de lo más singular", Instantes y azares, núm. 15-16 (2015): 45. Este énfasis en el proceso aparece en casi toda la obra tardía de Nietzsche, como en los fragmentos póstumos en que resalta esta idea respecto a la interpretación:
} 
De esta manera, en estos dos aspectos tenemos, por un lado, una metodología cínica, elegida a partir del destino de transvaloradores y, por otro, una autocreación como personajes improvisados que se entregan a la experimentación y al devenir para formarse. Asimismo, quisiera presentar dos anécdotas sobre Diógenes que permiten la analogía con el teatro. La primera dice: "Solía entrar en el teatro cuando los demás estaban saliendo; cuando le preguntaban por qué lo hacía, contestaba: 'Es lo que procuro hacer en mi vida entera"'. ${ }^{17} \mathrm{~A}$ la luz de su destino como inversor de todos los valores, Nietzsche habría podido decir exactamente lo mismo. Así, podemos considerar esta anécdota en su sentido más común: se trata de alguien que lleva la contraria (en Nietzsche podemos verlo en su carácter intempestivo, bélico -“Por naturaleza soy belicoso"-, ${ }^{18}$ antialemán; en Diógenes en su pelea contra la forma de hacer filosofía de Platón o contra la forma de vida de la ley y la ciudad; en ambos, en general, contra la moral y la fijación del sentido). Pero me interesa más pensarla desde su contexto teatral: cuando todos abandonan el teatro es precisamente cuando Diógenes entra. Cuando todos terminan de jugar su rol correspondiente en la escena (actor, director, espectador, etc.), Diógenes empieza ahí su performance $:^{19}$ donde nadie lo espera, donde no corresponde, cuando no corresponde. Diógenes perturba el orden del tiempo y del espacio, de la ficción y la realidad, tanto como Nietzsche ha perturbado la forma de hacer filosofía e incluso de hacer una autobiografía. De ambos podemos afirmar lo que Nietzsche dice de sí mismo: "Ich bin kein Mensch, ich bin Dynamit". ${ }^{20}$

La segunda anécdota es la siguiente: “A uno que le dijo: 'Estás filosofando sin saber nada', replicó: ‘Aunque solo esté fingiendo la sabiduría, también eso es filosofar'”. ${ }^{21}$ Al respecto, Branham observa: "Here Diogenes seems to affirm that the philosophic life is a kind of performance, an act, and thus to anticipate the idea of the philosopher as an adaptable

\footnotetext{
"No se debe preguntar: ‘quién interpreta entonces?', sino que el interpretar mismo, como una forma de voluntad de poder, tiene existencia (pero no como un 'ser', sino como un proceso, un devenir) como un afecto". Nietzsche, Fragmentos póstumos (Madrid: Tecnos, 2006) 2: 151.

${ }^{17}$ Diógenes Laercio, Vidas, opiniones y sentencias de los filósofos, trad. Luis Andrés Bredlow (Barcelona: Lucina, 2010), 64.

${ }^{18}$ Nietzsche, Ecce homo, 809.

${ }^{19}$ Esta idea de lo performático tiene que ver justamente con llevar lo teatral a espacios y circunstancias por fuera del lugar y tiempo propiamente teatrales. Es decir, de atravesar las leyes y los valores establecidos para lo teatral, como Adrian Parr lo afirma: "All performance art interrogates the clarity of subjectivity, disarranging the clear and distinct positions that the artist, artwork, viewer, art institution and art market ocuppy". Adrian Parr, The Deleuze Dictionary (Edinburg: Edinburgh University Press, 2005), 25.

${ }^{20}$ KSA VI, 365 ["No soy un hombre, soy dinamita". Nietzsche, Ecce homo, 853].

${ }^{21}$ Laercio, Vidas, opiniones, 64.
} 
actor". ${ }^{22}$ Aunque aquí la analogía con el actor es completa, Branham opaca esta idea en el resto de su texto al insistir en el carácter primordialmente retórico (y no filosófico) de Diógenes. Un énfasis como ese mantiene a las estrategias dramáticas de Diógenes como accesorias, como retóricas, y apenas relacionadas con la filosofía misma. El objetivo de este trabajo es pensar esos elementos teatrales como aspectos del pensamiento mismo, y no como formas para transmitirlo.

\section{Problemas del cinismo}

Quisiera aprovechar esta insistencia de Branham para discutir precisamente el significado de las historias en Diógenes y de su teatralidad. Se ha hecho notar el carácter polémico del cinismo, no sólo por su extravagancia, sino por lo dudoso de su perfil como forma del pensamiento. Michel Onfray ha realizado su trabajo alrededor de la filosofía del hedonismo, la filosofía antigua y la filosofía como forma de vida. Estas tres vertientes están estrechamente relacionadas y han sido inspiradas y justificadas teóricamente desde el mismo Nietzsche. En su contrahistoria de la filosofía, Las sabidurías de la antigüedad, Onfray rescata toda la historia del pensamiento que ha sido negada y ocultada de la historia oficial, representada especialmente por Platón y Hegel.

Onfray establece en el centro de su filosofía hedonista a Diógenes y a los cínicos, uno de los pilares de esa contrahistoria. Así, por el lado de la historia oficial, "Siempre listo a decir tonterías, Hegel afirmó de forma categórica en sus Lecciones de historia de la filosofía que, respecto a esta corriente filosófica, solo se pueden contar anécdotas. En consecuencia, Diógenes no es un filósofo". ${ }^{23}$ Para devolverle un lugar en la filosofía, Onfray se encarga de desentrañar el pensamiento detrás de las anécdotas, pero en su esfuerzo parece dejarnos únicamente con moralejas. Es cierto que así alguien puede formar una vida, pero la filosofía como terapéutica va mucho más allá que unos cuentos con enseñanza. La filosofía antigua

\footnotetext{
${ }^{22}$ Branham, "Defacing the Currency", 91 ["Aquí Diógenes parece afirmar que la vida filosófica es una especie de obra, un acto, y anticipa así la idea de que el filósofo es un actor adaptable". Los cínicos, 124].

${ }^{23}$ Michel Onfray, La fuerza de existir (Barcelona, Anagrama, 2006), 161.
} 
requiere una concepción de mundo que no es separable de la práctica misma. ${ }^{24}$ Para argumentar su punto, Onfray hace énfasis en que Diógenes también escribió, sólo que sus textos se han perdido. Es cierto, pero la lista de Laercio indica que escribió diálogos, cartas y tragedias, no tratados sistemáticos.

Onfray insiste en que las anécdotas no tienen un fin en sí mismas, que lo importante de ellas es su conclusión o su moraleja filosófica. Así, dirá respecto a Montaigne: “y tantos otros momentos preciosos más allá de la anécdota. Al menos, para el filósofo, el interés de estos detalles no está en la narración —en magnífico estilo_-, sino en el anzuelo: importan por su papel filosófico. [...] — medios de pensamiento y no fines en sí mismos". ${ }^{25}$ Esto es olvidar que ese carácter que sale a relucir en la anécdota tiene que ver con la opción de vida misma, que también es la concepción de mundo que el filósofo posee. Onfray separa forma y contenido; parece pensar que podría enseñarse esa misma filosofía de otra manera, lo que le reservaría un lugar en la academia al admitirse su carácter filosófico. ${ }^{26}$ Pero la ironía, la teatralización, las exclamaciones, el teatro, la escritura, constituyen ya una opción de vida por sí mismas, un carácter y una filosofía. Habría que llevar a sus últimas consecuencias la afirmación de Barthes en Crítica y verdad: "no hay más que una escritura". ${ }^{27} \mathrm{Ni}$ filosofía ni literatura: escritura. ¿Y qué significa esto? Pues bien, en este caso significa el teatro, el despliegue, el histrionismo, la hipérbole, porque si algo quieren estos textos - el cuerpo narrado de Diógenes; el cuerpo autobiografiado de Nietzsche-, es que no olvidemos que se trata siempre de una obra, y por esto las intertextualidades, las exageraciones y las inverosimilitudes, y hasta las sobreactuaciones.

La filosofía - la opción de vida que ambos eligen, la concepción de mundo bajo la que se rigen - tiene que ver con esa apertura dramática, se constituye en esa exposición del cuerpo y de las exclamaciones. Porque la vida así escrita (o así vivida) es el despliegue de la teoría, pero sin un antes ni un después de esta, sino que acontecen inseparablemente, como afirma Lozano-Vásquez: "Para Diógenes ser cínico es vivir; no hay nada que esté por encima

\footnotetext{
${ }^{24}$ Hadot hará constante referencia a esta idea respecto a la filosofía antigua: "Justamente lo que he querido mostrar es, sobre todo, que lo que considerábamos como pura teoría como abstracción, era práctica, tanto por su modo de exposición como por su finalidad”. Hadot, La filosofia, 139.

${ }^{25}$ Onfray, La fuerza, 66.

${ }^{26}$ Ya Barthes reconocía que era imposible escribir de manera diferente sin pensar de manera diferente: "Porque escribir es ya organizar el mundo, es ya pensar. Es pues inútil [...] pedir al otro que se re-escriba, si no está decidido a re-pensarse". Roland Barthes, Crítica y verdad (Buenos Aires: Siglo XXI, 1972), 33.

${ }^{27}$ Ibid., 47.
} 
de su cinismo, ni este es condición de posibilidad de algo más". ${ }^{28}$ Es decir que sus formas y actuaciones no se tratan de simples elementos didácticos o pedagógicos. Si la filosofía es filosofía práctica, si es la elección por una opción de vida, sus elementos formales no pueden estar por fuera de esa elección. ${ }^{29}$

En su afán por contradecir a Hegel, quien no supone ningún sentido a las anécdotas cínicas, Onfray devela el sentido oculto y verdadero: “Todas las anécdotas cínicas derivan del mismo principio: transmiten un sentido, portan un significado". ${ }^{30}$ Pero lo que se juega en esas anécdotas es precisamente la errancia del sentido. Fácil develar qué quiere decir Diógenes cuando anda buscando con una lámpara a la luz del día un hombre con una linterna, si vemos ahí una oposición al hombre ideal de Platón. ${ }^{31}$ ¿Pero qué sentido hay detrás de las anécdotas que evidentemente no pretenden ni enseñar ni simbolizar nada (la preferencia por el vino de otros, el anuncio de "cuidado" ya después de haber dado el golpe, etc.)? Es el juego del sentido, el de la imposibilidad de fijarlo, de lo que se duelen tanto Onfray como Hegel.

De la misma manera, la práctica no es un simple seguimiento de los preceptos teóricos. La práctica es una exposición, una exhibición, una manifestación, un performance donde la doctrina y la práctica son una y la misma. Como lo afirma A. A. Long: "it would be false to the nature of the Cynics movement to abstract a purely theoretical set of notions from the Cynics' deliberately bizarre styles of behavior and literary expression". ${ }^{32}$ Igualmente,

\footnotetext{
${ }^{28}$ Lozano-Vásquez, "Simbiosis entre", 10.

${ }^{29}$ Como Onfray, los autores del siglo XVIII que intentaron rescatar a la escuela cínica, limpiándola de aquello que podría resultar escandaloso para los ilustrados, terminaron vedándole justamente lo que podría hacerla valiosa. Ésta es la tesis que Louisa Shea presenta en su libro sobre la recepción de los cínicos durante la Ilustración: "One consequence of the Cynics' moral ambiguity, $[\ldots]$ is that by seeking to salvage Cynicism for social criticism the philosophes in fact contributed to the demise of the movement within Western intellectual history. By purging the sect of its less respectable traits, the philosophes in effect rendered Cynicism philosophically superfluous (their clean-shaven Diogenes proved, when all was said and done, a poor rival to the more traditional models of Socrates and Seneca)" [Una consecuencia de la ambigüedad moral de los Cínicos, [...] es que, al intentar salvaguardar el Cinismo para la crítica social, los filósofos de hecho contribuyeron a la muerte del movimiento dentro de la historia intelectual occidental. Al expurgar la secta de sus características menos respetables, lo que hicieron fue en efecto convertir al Cinismo en algo filosóficamente superfluo (al final, su Diógenes, tan pulcro, fue un rival débil contra los modelos tradicionales de Sócrates y Séneca)]. The Cynic Enlightenment: Diogenes in the Salon (Baltimore, The Johns Hopkins University Press, 2010), xiii).

${ }^{30}$ Onfray, La fuerza, 164.

${ }^{31}$ Michel Onfray, Las sabidurías de la antigüedad (Barcelona, Anagrama, 2007), 133.

32 Anthony Arthur Long, "The Socratic Tradition: Diogenes, Crates, and Hellenistic Ethics", en R. Bratch Branham y Marie-Odile Goulet-Cazé, The Cynics Movement in Antiquity and Its Legacy in Hellenistic Culture and Society (University of California: 1997), 29. ["Se falsearía la naturaleza del movimiento cínico si se abstrajera un repertorio puramente teórico de nociones a partir de los estilos, deliberadamente extravagantes, de conducta y de expresión literaria propios de dicho movimiento". "La tradición socrática", en Los cínicos, 48].
} 
Diógenes no es siempre consecuente y podemos encontrar muchas contradicciones entre su doctrina y sus anécdotas, como entre sus anécdotas mismas. A nadie se le ocurría ir a tenderle trampas para acusarlo de contradicción, como sí a Pirrón, quien debía siempre excusarse y explicarse cuando no lograba cumplir a cabalidad los preceptos del escepticismo, según cuenta Laercio. A los pocos que se atrevían a esta empresa, Diógenes siempre encontraba la manera de ridiculizarlos. ${ }^{33}$ Está en juego una estrategia teatral que nos dice algo, pero no como simple instrumento al servicio de la teoría, no se desecha, sino que permanece después de haber cumplido una función comunicativa: la ironía está atada a lo dicho, el juego de palabras a las palabras. Lo que Diógenes no nos deja olvidar es justamente sus maneras, exactamente igual que Nietzsche permanece en las formas en que se ha dicho a sí mismo (considera a Zaratustra su mejor voz, por ejemplo). ${ }^{34}$ Aquí los márgenes de la filosofía se nublan, para acercarse a los del teatro y la literatura, donde la división forma/contenido no tiene cabida. ${ }^{35}$

Para Onfray, el cinismo es su doctrina y nada más: una vida frugal, un retorno a la naturaleza, un desprecio por las normas sociales: "La lección hubiera podido darse sin tanta teatralidad, tanto énfasis o tanto derroche de astucia en la ironía, y las conclusiones habrían sido las mismas". ${ }^{36}$ Pero esta doctrina está demasiado cercana a otras que por la misma época estaban en boga, y si algo ha sobrevivido y resaltado el acontecer cínico son las anécdotas de Diógenes. Es cierto que gran parte de la tradición las ha despachado simplemente como tales,

33 "Como alguien le reprochaba que estuviera bebiendo en una taberna, dijo: 'También me hago cortar el pelo en la barbería"'. Laercio, Vidas, opiniones, 66.

34 "Es preciso ante todo oír bien el sonido que sale de esa boca, ese sonido alciónico, para no ser lastimosamente injustos con el sentido de su sabiduría". Nietzsche, Ecce homo, 785.

${ }^{35}$ Según Paul Valéry, esto es lo que sucede en el lenguaje poético, a diferencia de la comprensión en el discurso común: "Comprender consiste en la sustitución más o menos rápida de un sistema de sonidos, de duraciones y de signos por una cosa muy distinta, que es en suma una modificación o una reorganización interior de la persona a la que se habla. [...]. Por consiguiente, la perfección de un discurso cuyo único objeto es la comprensión consiste evidentemente en la facilidad con la que la palabra que lo constituye se transforma en algo muy distinto, y el lenguaje, ante todo en un no lenguaje; y a continuación, si así lo queremos, en una forma de lenguaje diferente de la forma primitiva. En otros términos, en los empleos prácticos o abstractos del lenguaje, la forma, es decir, lo físico o lo sensible, y el acto mismo del discurso no se conserva; no sobrevive a la comprehensión; se disuelve en la claridad; ha actuado; ha cumplido su función; ha hecho comprender: ha vivido. Pero, por el contrario, tan pronto como esta forma sensible adquiere por su propio efecto una importancia tal que se impone, y se hace, de alguna manera, respetar; y no sólo notar y respetar, sino también desear y por lo tanto recuperar - cuando algo nuevo se declara: estamos insensiblemente transformados, y dispuestos a vivir, a respirar, a pensar de acuerdo con un régimen y bajo leyes que ya no son del orden práctico- - [...]. Entramos en el universo poético". Paul Valéry, "Poesía y pensamiento abstracto", Teoría poética y estética (Madrid: Visor, 1990), 85-86.

${ }^{36}$ Onfray, Las sabidurias, 134. 
pero su reivindicación para otra concepción de la filosofía no puede consistir simplemente en alertar que detrás de las anécdotas hay una doctrina, un pensamiento. Su reivindicación tiene que venir del pensamiento y la filosofía que ellas mismas encarnan, no del que simplemente representan y que supondría la filosofía como contenido para ser representado en el teatro, en las anécdotas, en la vida. Por el contrario, antes de evocar un sentido, lo que podemos notar en la sucesión de anécdotas es su provocación: no importa sólo lo que dice Diógenes, sino todo el espectáculo. ${ }^{37}$ Es más, no son únicamente escenas que pretenden enseñar a partir de sus maneras (el escándalo, el humor, la ironía) y que permiten la recordación o la inclinación, cumpliendo un papel ejemplarizante, sino que constituyen como un todo la puesta en escena de la imposibilidad de fijar un sentido. Únicamente poseemos lo que dice el actor, el escenario, los demás participantes de la escena, el público, el lector: nunca la voz última y definitiva de la escuela, la doctrina, el sentido, el autor.

La dualidad de Onfray podría resumirse así: la doctrina (interior) debe verse reflejada en el discurso o la vida (exterior). Diógenes destruye este orden: la vida acontece con la doctrina. La vida es la filosofía, es el pensamiento, y esta vida/pensamiento se desarrolla en una puesta en escena. Es a partir de sus acciones, de sus respuestas y de sus dichos que su pensamiento se despliega, sus maneras son tan fundamentales como lo que dice y hace a través de estas. El cinismo de Diógenes no tiene afuera, está libre de la persecución que sufrían estoicos y escépticos, vigilados para que permanecieran en su vida siempre dentro de los límites de su doctrina.

\section{Problemas de Ecce homo}

Me gustaría seguir hablando en esta segunda parte de este trabajo desde Ecce homo, dejando a Diógenes en un provisional papel secundario, para pensar las dicotomías que se proponen

\footnotetext{
${ }^{37}$ Lozano-Vásquez afirma al respecto: "Lejos de la naturalidad que en voz alta promulgan, las actitudes de Diógenes o la invención de éstas por parte de sus biógrafos están fríamente calculadas. Muestran el desinterés del cinismo por los valores sociales fundamentales como el pudor, el estatus, la fortuna en la política y en el amor, la hospitalidad...etc. Pero además pretenden provocar la risa y llamar la atención; Diógenes es probablemente el primer iconoclasta, figuradamente hablando, intenta siempre ser un golpe de opinión. Su estrategia es publicitaria; es decir pretende conseguir recordación, inclinación y apropiación". Lozano-Vásquez, "Simbiosis entre", 13.
} 
para la interpretación de las vidas de ambos personajes y ver cómo ellos entran a destruirlas. Aquí aparece Nietzsche, quien se juega su ejercicio vital en la escritura misma desplegada como puesta en escena, tal como afirmaba Barthes en la cita inicial de este trabajo. La escritura así no es medio para representar una doctrina, sino que equivale al ejercicio mismo del pensamiento permitido por el juego de los signos. ${ }^{38}$

De esta manera, la dualidad vida-obra, hombre-filósofo, no se supera cuando entendemos la filosofía como práctica en un sentido donde el pensador es consecuente en su vida respecto a su doctrina. En general, es ésta la concepción que se tiene para entender lo que Nietzsche trata de recuperar de la filosofía antigua. Veamos, por ejemplo, una afirmación de Germán Meléndez, en un análisis de Ecce homo, que supuestamente desdibuja la acostumbrada separación entre filosofía y vida: "Lancemos ahora una rápida mirada al resto del prólogo a $E H$ en busca de los primeros indicios referentes al hombre detrás de sus escritos". ${ }^{39}$ Sin embargo, un ejercicio autobiográfico redistribuye y confunde de la mejor manera los dualismos propuestos, pues se trata de una escritura - generalmente concebida como la parte doctrinal — de una vida — concebida como la parte práctica—. ${ }^{40}$ Así, no hay "hombre detrás de los escritos", sino que en la escritura misma el hombre se ha hecho tal, con la consecuencia de que la escritura también se ha encargado de develarlo y esconderlo, de entregarlo tal como es y también de confundirlo. Éste es un proceso que la escritura como teatro opera sobre todos los signos que participan de ella, pero que una escritura (y, por ende, una subjetividad) como la de Nietzsche llevan al extremo; pues quien es "eine ungeheure

38 Claramente Zaratustra es el mejor ejemplo porque expone explícitamente los artefactos, el juego es evidentemente juego: es un teatro sin verosimilitud, pues se devela como teatro. Esta forma no es accesoria: "Er redet nicht nur anders, er ist auch anders" KSA VI, 260. [" $\{$ Zaratustra $\}$ no solo habla de manera diferente, también es diferente". Nietzsche, Ecce homo, 783]. De esta manera, en Ecce homo sucede lo mismo: los títulos de los capítulos. "Por qué soy tan inteligente", "Por qué soy un destino", etc.), las exclamaciones, las citas, las autocitas, las parodias de citas, las hipérboles, las contradicciones (inclusive las "mentiras" -lo que no corresponde al Nietzsche histórico), todos estos elementos juegan de forma evidente para que aquello que dicen aparezca siempre dramatizado, desplazando el sentido.

39 Germán Meléndez, "Filosofía como autoconfesión de su autor", Convertir la vida en arte (Bogotá: Universidad Nacional de Colombia, 2016), 283.

40 Éste sería justamente el deseo de Nietzsche: "El filósofo del futuro es al mismo tiempo el explorador de los viejos mundos, cimas y cavernas, y solo crea a fuerza de recordar algo que fue esencialmente olvidado. Ese algo, según Nietzsche, es la unidad del pensamiento y de la vida". Gilles Deleuze, Spinoza. Kant. Nietzsche (Barcelona: Labor, 1974), 211. El mismo Deleuze podría darnos una correspondencia entre Diógenes y Nietzsche, entre la biografía de uno y la autobiografía del otro: "La unidad que convierte una anécdota de la vida en un aforismo del pensamiento y una evaluación del pensamiento en una nueva perspectiva de la vida". Ibidem. 
Vielheit, die trotzdem das Gegenstück des Chaos ist", ${ }^{41}$ está desplegando de la misma manera su escritura (no hay nada por fuera de ella). Así, la obra dramática que toda la obra de Nietzsche es, y que lo tiene a él como personaje protagónico, es una puesta en escena de la escritura, pero confundirlo es sumamente fácil por lo particular que es la subjetividad que estamos tratando. Por esta razón, el Ecce homo es necesario: allí se afana por explicitar qué es, aunque ese ser sea demasiado particular ("Para la tarea de una transvaloración de los valores eran tal vez necesarias más facultades que las que jamás han coexistido en un solo individuo, sobre todo también antítesis de facultades"). ${ }^{42}$ ¿Cómo es posible que esto no se preste para equivocaciones? Aquí está precisamente lo difícil, lo susceptible a malinterpretarse, a confundirse. El caso de Diógenes es exactamente el mismo. Alguien podría guardar en el recuerdo las anécdotas del cínico en las que se enfatizaba su vida frugal. Otro se quedaría con las historias de las tabernas. Quien sólo se queda con uno de estos extremos posee una visión parcial, mientras habrá quien los una y vea una contradicción. ¡Pero sería como acusar a un actor de falso por interpretar dos papeles diferentes en la misma obra! ¿Quién es, pues, Nietzsche? De nuevo Deleuze es iluminador al respecto:

En Nietzsche todo es máscara. Su salud es una primera máscara para su genio; sus sufrimientos, una segunda máscara, a la vez para su genio y para su salud. Nietzsche no cree en la unidad de un Yo, y no lo siente: relaciones sutiles de poder y de evaluación entre diferentes 'yo' que se ocultan, pero que también expresan fuerzas de otra naturaleza, fuerzas de la vida, fuerzas del pensamiento - esa es la concepción de Nietzsche, su manera de vivir- . Nietzsche vivió a Wagner, a Schopenhauer, e incluso a Paul Ree, como sus propias máscaras. [...] Entre los más elevados momentos de la filosofía de Nietzsche se cuentan las páginas en las que habla de la necesidad de enmascararse, de la virtud y de la positividad de las máscaras, de su instancia última. [...] sobre esta primera máscara, otra, representada por el enorme bigote. 'Dame, te lo ruego, dame... — ¿Qué? - Otra máscara, una segunda máscara'. ${ }^{43}$

Es justamente en el juego de las máscaras donde hay un carácter que permanece, un centro de gravedad, un estilo: el performático. No se trata, pues, de la develación de un sentido. El título de la autobiografía de Nietzsche no debe interpretarse como la autoproclamación, la

\footnotetext{
${ }^{41}$ KSA VI, 294. "Una multiplicidad, que, sin embargo, es lo contrario del caos". Nietzsche, Ecce homo, 807. La particularidad de Nietzsche es que ha llegado al punto máximo en cuanto a esto; Alexander Nehamas lo definirá como "el mínimo de discordia entre el máximo de tendencias diferentes". Alexander Nehamas, Nietzsche, la vida como literatura (México: Fondo de Cultura Económica, 2002), 224.

${ }^{42}$ Nietzsche, Ecce homo, 806.

${ }^{43}$ Deleuze, Spinoza, 206.
} 
univocidad y la vanidad. "He aquí el hombre" refiere más bien a un hombre demasiado particular, sui generis, nuevo y diferente a los demás, un hombre que es un despliegue de fuerzas de las cuales sólo vemos máscaras y que incita a la errancia a aquel que quiera definirlo, doblegarlo: "Jerarquía de las facultades; distancia; el arte de separar sin enemistar; no mezclar nada, no 'conciliar' nada; una multiplicidad enorme, que es, sin embargo, lo contrario del caos - esta fue la condición previa, el trabajo y el arte prolongados y secretos de mi instinto". ${ }^{4}$

Para terminar, me gustaría devolver al escenario a los dos personajes principales de este trabajo para un último diálogo a partir del ensayo de Niehues-Pröbsting sobre la recepción moderna de los cínicos. ${ }^{45}$

En este artículo se dedica un importante espacio a la interpretación que Nietzsche hizo del cinismo:

Nietzsche directed his interest beyond the merely historical question and inquired what possibilities Cynicism could offer beyond its historical uniqueness and past: possible modes of living; moral possibilities, particularly the problematization and critique of morals; possibilities of shedding light on morals; possibilities of an enlightened personal style critical of morals; rhetorical-literary and polemical possibilities. ${ }^{46}$

Lo que este trabajo ha propuesto hasta ahora es que las dos últimas posibilidades que Niehues-Pröbsting encuentra son las que enmarcan a las demás; es decir, el estilo, la ironía, la parodia, el humor, en una palabra, todo lo que corresponde al performance del personaje, es justamente el modo de vida, la problematización y crítica de la moral, una idea fundamental del pensamiento y la filosofía de Nietzsche. Esto es, no simplemente el uso de

\footnotetext{
${ }^{44}$ Nietzsche, Ecce homo, 806.

${ }^{45}$ Niehues-Pröbsting es el único autor que Michel Foucault recomienda en sus clases sobre la parrhesía, para profundizar en el tema del cinismo. Michel Foucault, "Clase del 7 de marzo de 1984", El coraje de la verdad (Buenos Aires, Fondo de Cultura Económica, 2009), 206.

${ }^{46}$ Heinrich Niehues-Pröbsting, "The Modern Reception of Cynicism: Diogenes in the Enlightenment”, en The Cynics, 354 ["En sus reflexiones, [Nietzsche] dirigió su interés más allá de la cuestión meramente histórica, e indagó qué posibilidades podía ofrecer el cinismo trascendiendo su especificidad histórica y su pasado: posibles modos de vida, posibilidades morales, en particular la problematización y la crítica de la moral; posibilidades de proyectar luz sobre la moral, posibilidades de un estilo personal ilustrado, crítico de la moral; y su posibilidades retórico-literarias y polémicas". "La recepción moderna del cinismo: Diógenes y la Ilustración", en Los cínicos, 641].
} 
figuras retóricas para transmitir un pensamiento, sino la necesidad de esas figuras como posibilidades del pensamiento mismo; no el uso de esas figuras para transmitir un contenido, sino la absoluta indiferenciación entre forma y contenido en esas figuras desplegadas a través del performance. Sin esta teatralidad, sin la puesta en escena de este pensamiento, las figuras utilizadas caerían simplemente bajo el calificativo de suplementarias. Una de las formas de vida que implica este drama es la de concebir lo que en la filosofía es solo forma y método (al servicio siempre de un contenido), como la confusión de forma y contenido, de la misma manera en que vida y obra se confunden en el Ecce homo.

Así es como Niehues-Pröbsting también lo afirma:

However, Cynicism did not gain its highest importance in and for Nietzsche as a positive moral philosophy, as instruction for happiness or precepts for life, but as a certain paradigm of the criticism of morals and of an enlightenment critical of morals. Nietzsche discovered Cynicism as a position beyond good and evil, as a didactic play of the free spirit. ${ }^{47}$

Podemos concluir de la siguiente manera: el énfasis está en la actitud, en la posición, en el juego, lo que concretamente en el caso de Diógenes es provocación, sátira, bufonada. ${ }^{48}$ Nietzsche mismo dirá: "No conozco ningún otro modo de tratar con tareas grandes que el juego". ${ }^{49}$ Ante este tipo de prácticas parece haber una tentación de cerrar sus posibles lecturas de dos formas: primero, como Hegel, suponer que son formas vacías (y, por ende, chistes, meramente), o, por otro lado, como Onfray, interpretar a partir de lo que representan, develarlas, reconstruir su sentido oculto. La posición que he querido defender aquí tiene que ver con algo muy diferente: "Cynicism is the conscious and demostrative rejection of a

\footnotetext{
${ }^{47}$ Íbid., 359. "Pero el cinismo no alcanzó su máxima importancia en ni para Nietzsche como una filosofía moral positiva, como instrucción para la felicidad o como preceptos para la vida, sino como un cierto paradigma de crítica de la moral y de una ilustración crítica de la moral. Nietzsche descubrió el cinismo como una postura más allá del bien y del mal, como una representación didáctica del libre espíritu” (467).

${ }^{48}$ Entre las posibilidades de un cinismo antiguo actualizado en el siglo XX, Peter Sloterdijk presenta al dadaísmo como un representante digno de Diógenes de Sinope. Su conexión se presenta, entre otras cosas, justamente por sus ataques provocadores y performáticos: "Con el dadá hace su aparición en escena el primer neoquinismo del siglo XX. Sus golpes se dirigen contra todo lo que se toma en serio: sea en el ámbito de la cultura y de las artes, sea en el de la política y la vida burguesa. No ha habido otra cosa que haya golpeado en nuestro siglo tan airadamente el espirit de sérieux como el martilleo dadaísta" (Crítica de la razón cínica (Madrid: Siruela, 2007), 563). (El primer resaltado de la cita es mío).

${ }^{49}$ Nietzsche, Ecce homo, 808.
} 
required moral attitude. The moral attitude is pushed aside and replace, for example, by a comical attitude: at that point cynical humor comes into being", 50

De esta manera, el pensamiento, la filosofía que hay en el performance cínico, con el que estoy caracterizando tanto la vida de Diógenes como la escritura de Nietzsche, se trata, primero, de una resistencia al sentido último, de una develación de la fijación de sentido como ficción, de una inclinación hacia lo múltiple; y, por otro lado, pero muy de la mano de lo que acabo de señalar, se trata también de un rechazo a la moral como concepción del mundo, como sentido último del hombre. Allí donde Niehues-Pröbsting ha dicho "humor" yo quisiera decir performance, para incluir todos los aspectos dramáticos de ambos personajes, entre los que claramente se encuentra el humor. Por esta razón, la puesta en escena de Diógenes y Nietzsche que presenciamos es muy similar a la del bufón inoportuno que dice incoherencias, que ofende y provoca, pero que dice la verdad, tal como el teatro nos lo ha recordado desde siempre.

\footnotetext{
${ }^{50}$ Pröbsting. "The Modern", 360. "El cinismo es el rechazo consciente y demostrativo de una actitud moral impuesta. La actitud moral se deja de lado y se reemplaza, por ejemplo, por una actitud cómica: en ese punto nace el humor cínico" (469).
} 


\section{Bibliografía}

Bajtín, Mijail. Teoría y estética de la novela: trabajos de investigación. Madrid: Taurus, 1989.

Barrenechea, Miguel Ángel de. “Ecce homo: La universalidad de lo más singular”. Instantes y Azares, núm. 15-16 (2015).

Barthes, Roland. Crítica y verdad. Buenos Aires: Siglo XXI, 1972.

Barthes, Roland. Lección inaugural. México: Siglo XXI, 1993.

Branham, R. Bratch. "Defacing the Currency: Diogenes' Rhetoric and the Invention of Cynism”. En R. Bratch Branham y Marie-Odile Goulet-Cazé, The Cynics: Movement in Antiquity and Its Legacy in Hellenistic Culture and Society. Berkley, CA: University of California, 1997.

Deleuze, Gilles. Spinoza. Kant. Nietzsche. Barcelona: Labor, 1974.

García Gual, Carlos (ed.). Vidas, opiniones y sentencias de los filósofos. Madrid: Alianza, 2007.

Hadot, Pierre. La filosofía como forma de vida: conversaciones con Jeannie Carlier y Arnold I. Davidson. Barcelona: Alpha Decay, 2009.

Laercio, Diógenes. Vidas, opiniones y sentencias de los filósofos. Trad. Luis Andrés Bredlow. Barcelona: Lucina, 2010.

Long, Anthony Arthur. "The Socratic Tradition: Diogenes, Crates, and Hellenistic Etics”. En R. Bratch Branham y Marie-Odile Goulet-Cazé, The Cynics Movement in Antiquity and Its Legacy in Hellenistic Culture and Society. Berkley, CA: University of California: 1997.

Lozano-Vásquez, Andrea. "Simbiosis entre vida y doctrina en Vidas de filósofos ilustres". Simposio Discurso y vida en la Antigüedad. Medellín: Universidad de Antioquia: 2014.

Meléndez, Germán. "Filosofía como autoconfesión de su autor". Convertir la vida en arte. Bogotá: Universidad Nacional de Colombia, 2016.

Nehamas, Alexander. Nietzsche, la vida como literatura. México: Fondo de Cultura Económica, 2002.

Niehues-Pröbsting, Heinrich. "The Modern Reception of Cynicism: Diogenes in the Enlightenment”. En R. Bratch Branham y Marie-Odile Goulet-Cazé, The Cynics 
Movement in Antiquity and Its Legacy in Hellenistic Culture and Society. Berkley, CA: University of California: 1997.

Nietzsche, Friedrich. Ecce homo. En Obras Completas IV: Escritos de madurez II. Edición dirigida por D. Sánchez Meca. Madrid: Tecnos, 2016.

Nietzsche, Friedrich. Los filósofos preplatónicos. En Obras Completas II: Escritos filológicos. Edición dirigida por D. Sánchez Meca. Madrid: Tecnos, 2013.

Nietzsche, Friedrich. Fragmentos póstumos. Madrid: Tecnos, 2006.

Onfray, Michel. La fuerza de existir. Barcelona: Anagrama, 2006.

Onfray, Michel. Las sabidurías de la antigüedad. Barcelona: Anagrama, 2007.

Parr, Adrian. The Deleuze Dictionary. Edinburg: Edinburgh University Press, 2005.

Shea, Louisa. The Cynic Enlightenment: Diogenes in the Salon. Baltimore: The Johns Hopkins University Press, 2010.

Sloterdijk, Peter. Crítica de la razón cínica. Madrid: Siruela, 2007.

Valéry, Paul, "Poesía y pensamiento abstracto". Teoría poética y estética. Madrid: Visor, 1990. 